\title{
NATIONALITY AS A STIGMA: THE DRAWBACKS OF NATIONALITY (WHAT DO I HAVE TO DO WITH BOOK-BURNERS?)
}

BOLDIZSÁR NAGY

\begin{abstract}
The study deals with two related issues: first with the conundrum of the Hungarian law on nationality and voting rights; second with instances when nationality acts as a stigma. It has two major propositions. First, the Hungarian law on nationality and elections does not lead to any reasonable conclusion concerning who constitutes the Hungarian political community, as millions of Hungarian nationals are practically excluded - but an ever increasing crowd of people who have never lived in Hungary but are descendants of nationals of the Hungarian Kingdom (and who are therefore entitled to preferential naturalization and rewarded with voting rights), are. So a clearly ethnic-cultural nationalist discourse has led to the adoption of a system of rules which in essence serves one purpose: the creation of a faithful clientele. Second, nationality in the present form, usually based on ius sanguinis and ius soli is not tenable from the moral- and political-philosophical point of view as it does not differ from a feudal privilege, also determined by accident of birth into a family or in one place. The specific burdens that differentiate nationals from settled foreigners are also reviewed in this paper. The conclusion is that nationality should be reformulated along the lines of Rainer Bauböck and Ayelet Shachar's thinking; that is, rights entailed in nationality should derive from attachment to a given community, and from the fact that the decisions of the body politic directly affect the person.
\end{abstract}

KEYWORDS nationality, political community, voting rights, stigma, feudal privileges, ius sanguinis, ius soli

1 Boldizsár Nagy is associate professor of international law at CEU and ELTE; e-mail: nagyboldi@ajk.elte.hu. This paper is based on a lecture held at the conference "Nationality, naturalisation, integration - 20 years of the nationality law" held at the Hungarian Academy of Sciences on 25 November 2013. A Hungarian version of this text appears in Regio. The author is grateful to Adam Barkl who kindly assisted with improving the paper's language style. 


\section{A DIFFERENT LOOK AT THE INSTITUTION OF NATIONALITY}

Hungarian public discourse presents nationality as a gift. Whoever gets it should feel as if they have been blessed. Whoever does not partake of it looks as if they are cut off from the body of the nation. However, whenever someone of a non-Hungarian ethnic background wishes to be naturalised, then a question pops up: "Whyever does this individual wish to get closer (enter, immigrate) to the land of Hungarians (of Hungarian nationals)?"

The purpose of this study is to take a different look at nationality, put down the lens of the EU citizen living in a (more or less) welfare state, ignore for a moment the indoctrination of 19th century nationalism that is obsessed with state-building and dreaming of ethnically homogenous nation-states, and investigate the possible drawbacks attached to certain nationalities. The aim is to identify the disadvantages of an individual being identified with a random set of people (a group of fellow nationals) rather than with her own character, deeds, past and ambitions. Identification along the lines of nationality is nothing but an institutionalised prejudice: if someone is a national of a state, and she has violated the rules (on immigration, legal stay, employment, etc.) of another state, then her fellow national presumably is also a potential violator of those laws. Therefore the decision maker of that state (visa-authority, immigration officer, confidentiality or reliability assessor) should refuse, exclude, or keep away that other person, who actually has not committed any offence (yet).

Of course, Hannah Arendt and the demand to have the right to enjoy rights are not forgotten, ${ }^{2}$ neither is the misery entailed in statelessness lost sight of. ${ }^{3}$ Therefore this study does not attack the existence and use of nationality; neither does it challenge the fact that possession of a nationality is a human right. ${ }^{4}$ Statelessness makes one even more defenceless than the worst nationality.

2 "We became aware of the existence of a right to have rights (and that means to live in a framework where one is judged by one's actions and opinions) and a right to belong to some kind of organized community, only when millions of people emerged who had lost and could not regain these rights..." Arendt (1958:297-298

3 An unusual source, The Supreme Court of the UK: "The evil of statelessness became better understood following the re-drawing of national boundaries at the end of the two world wars of the twentieth century and following, for example, the Reich Citizenship Law dated 15 September 1935 which provided that all Jewish people should be stripped of their citizenship of the German Reich” Al Jedda v SSHD [2013] UKSC 62., 12. para. See also: Molnár (2014)

4 Article 24 of the International Covenant of Civil and Political Rights 
The starting point of this study may best be illustrated by the following (partly hypothetical) example: let us assume that a genuinely democratic state's government notes that in November 2013 in Hungary presumably fascist certainly anti-Semitic - Hungarian nationals burned books, among others, those of Miklós Radnóti, one of Hungary's greatest poets, killed because of his Jewish background in 1944. ${ }^{5}$ The law enforcement agencies did not act. No state retorsion was initiated. Let us assume that this genuinely democratic state becomes convinced that if these activities be remain unsanctioned in Hungary, then all Hungarian nationals must be infected with the virus of fascism and anti-Semitism and so should never get an entry or immigration permit into that democratic state. Only through this drastic measure can potential Hungarian immigrants or visitors be prevented from shocking the inhabitants of the democratic country and challenging their conviction that all human beings, without exception, are equal.

That hypothetical step, a total ban on entry, would, beyond doubt, be followed by a storm of indignation in Hungary. Protest would claim that, "Those Hungarian nationals are different, and we have nothing to do with them. Their vicious views are not shared. Let us be assessed according to our own standpoints."

The question is the following: on what basis does the one who does not identify herself with her barbaric fellow nationals group together, as it may be, a billion persons with those few ten-thousands, who may have committed much smaller misdeeds, such as overstaying their visas or taking illegal employment? How can full communities of other nationals be designated as risky, when in one's own case this is exactly the target of passionate protest?

This study confronts this dilemma. In our own cases we are ready to identify with the better sides of our nation and project our dark sides onto an imagined other ${ }^{6}$, whereas nationals of other nations are frequently judged by the reprehensible acts of their fellow nationals, while having their virtues ignored.

Nationality is like stigma: a stamp, a sign, which literally refers to the branding of animals or slaves, but which in the Christian world also refers to the chosen; those who have Jesus' wounds appear on them, those who feel his pain (Goffman, 1963:1,4). Nationality similarly has a dual character: it may entail being branded, excluded or designated as inferior, but it may also reflect

5 See: http://jovonk.info/2013/11/15/megtisztulas-ejszakaja-miskolcon (2014-07-25)

6 A recent example of this dual vision is the monument set up in Budapest in Szabadság Square which it is claimed refers to the victims of the German occupation of Hungary in 1944, but is regarded by many as an effort to whitewash Hungarian participation in fascist crimes. 
the idea of being chosen. The dominant perspective depends on, first, where the individual is born, and second, on the viewpoint of the assessing agent: does she see in the foreigner the scary "other" or does the motive to find a common blood and ancestry dominate - the need to find a shared mystical identity based on tribal belonging?

This study has a dual agenda. First, it proves that Hungarian legislation on nationality has lost its direction and is maintaining an inconsistent system which is unintelligible from the political philosophical point of view. Second, expanding the horizon, it engages with the fact that the majority of the world's population is excluded from a better life or meaningful self-determination. They are excluded from freedom by their nationality.

\section{THE CONTEXT OF NATIONALITY: STATE, NATION, BODY POLITIC - COMPLETE CONFUSION IN HUNGARY}

Who constitutes the state? Who are the people that are the source of public power? Who belongs to the Hungarian nation? And of whom is the body politic constituted? The Hungarian legislator has created chaos in the last two decades which has culminated in the adoption of amendments to the nationality law and the new law on elections. ${ }^{7}$

In 2001 the conservative government (whose personal constitution hardly differed from the one that existed between 2010 and 2014) still made a clear difference between the support granted to those chosen on an ethnic basis and the support given to those who freely declared themselves ethnic Hungarian by way of individual self-identification. It condemned the former and approved the latter. The government stressed that the benefits granted by the law to Hungarians living in the neighbouring countries (the Status-law) ${ }^{8}$ cannot be compared to dual nationality granted on an ethnic basis to persons living in neighbouring countries, as the latter would have irredentist overtones. It stated: "When drawing up this piece of legislation, the Hungarian Government - and indeed the Parliament which adopted the Act by a 92\% majority - set aside all aspirations for any kind of dual citizenship for persons belonging to Hungarian national minorities and living in the neighbouring countries, and instead preferred a system based on co-operation ... Hungary is convinced that this Act confirms [in] the most apparent way the refutation of any kind of

7 Act No. XLIV of 2010 amending Act No. LV. of 1993 on nationality and Act No. CCIII. of 2011 setting out the new rules on the election of members of Parliament

8 Act LXII. of 2001. on Hungarians living in neighbouring states 
territorial revision as a 'solution' for questions raised by national minorities." (Point 1.8.) "In fact, the Act recognises that Hungarians abroad are citizens of the relevant states and clearly rejects the idea that the self-identification as Hungarians can be based on dual citizenship. ... In the expression of its kin-state role, Hungary has always acknowledged that it has no citizen-like relationship whatsoever with Hungarians living in the neighbouring countries when dealing with them." (Points 2.3 and 6.1.) (emphasis added). ${ }^{9}$

This is no longer the case. According to the new dogma, granting nationality to members of the ethnic (national) minority, who continue to reside in their original domiciles, promotes the maintenance of contacts with the kin-state and the "preservation of Hungarianhood"10. The short (altogether 11-paragraph-long) explanatory note that accompanies the bill, introducing naturalisation on preferential terms, devoted a mere five paragraphs to justifying the naturalisation of persons without a residence in Hungary. These stated that "among Hungarians living in the world and in the Carpathian basin, again and again the demand surfaced in the last 20 years that the introduction of naturalisation on a preferential basis - following the examples of other countries - would enhance the keeping of contact with the kin state and the preservation of Hungarianhood. The purpose of the bill is to assure 'dual nationality'; that is, naturalisation on a preferential basis to Hungarians living beyond the border by way of amending Act No. LV. of 1993 on Hungarian nationality." How would mere nationality enhance keeping contact with the kin-state, especially if both of them are EU members? What does "preservation of Hungarianhood" mean? The explanatory note does not deliver answers to these questions; neither does it address the issue of whether those one and a half million persons who choose to self-identify as Hungarian but who will not apply for naturalisation on preferential terms, are indeed hindered in keeping contact with the kin-state. Nor do we learn why preserving "Hungarianhood" without applying for nationality would become more cumbersome.

Zsolt Semjén, the competent deputy prime minister, in his speech at the Parliament introducing the bill ${ }^{11}$ referred to national solidarity, the "healing of

9 Paper containing the position of the Hungarian government in relation to the act on Hungarians living in neighbouring countries CDL (2001) 80 Strasbourg, 21 August 2001. Available at: http://www.venice.coe.int/webforms/documents/?pdf=CDL(2001)080-e (2014-07-25)

10 "Hungarianhood" is used here and not "Hungarian identity", because the original Hungarian term "magyarság" is so essentialist that its translation as "Hungarian identity" would not reflect its primordial connotations.

11 Speech of Zsolt Semjén, deputy prime minister when introducing the amendment to the 1993 Act on Nationality in: http://www.allampolgarsag.gov.hu/index.php?option=com content\&view $=$ article \&id $=142:$ semjen $\&$ catid $=43:$ torveny \&Itemid $=72(2014-07-26)$ 
the wound" of the unsuccessful 2004 referendum ${ }^{12}$, the correction of the Trianon peace treaty that deprived Hungary of $2 / 3$ of its territory after the first World War, when - in his words - "a third of the nation was transferred under alien jurisdiction"13, and then he went on to claim that the planned Act "does neither grant extra rights, nor does it diminish the rights of anyone. Their [Semjén is presumably speaking here of the preferentially naturalised] situation is similar to other Hungarian nationals living abroad. Accordingly, there is no A and B category Hungarian nationality, there is no first class and second class. There is one Hungarian nation, there is a single Hungarian nationality." 14

This change clearly made the Status law on the assistance to Hungarians living in the neighbouring countries a truly confusing instrument as it now extends to Hungarian nationals who live in neighbouring countries (except for Austria) and identify themselves as Hungarians, but its benefits cannot be enjoyed by Hungarian nationals who live within Hungary or in other (nonneighbouring) countries. Neither does it extend (at least formally) to those Hungarians who do not "declare themselves to be of Hungarian ethnicity" - to use the words of the Status law itself. Curiously enough, the nationality law as amended - contrary to its earlier form and to the Status law - does not require that the person who is naturalised self-identifies herself as Hungarian. The oath that must be sworn avoids any reference to national belonging and limits itself to requiring that the naturalised person swear or pledge that she shall regard Hungary as her country and shall be a loyal citizen of the Republic of Hungary. The new national shall respect and obey the Constitution and the laws and shall protect the country as her strength allows, and serve it to the best of her ability, so help her God.

The Government, back in 2001, defended the Status law by claiming that the Act "does not have any direct or indirect/implied reference to 'ethnie' as a basis for receiving benefits from the Hungarian state. Ethnic ties are based on blood relationships (ius sanguinis) and on association with a 'homeland' and on the myths of the past. In contrast, the aim of the present Act is to promote and preserve the well-being and awareness of the national (language,

12 http://valasztas.hu/nepszav04/main_hu.html (2014-05-21) Out of the valid votes 1521271 were in favour of introducing preferential naturalization and 1428578 against.

13 As a consequence of the Trianon Peace treaty that concluded the First World War, the proportion of Hungarians among the whole population grew from $54,5 \%$ to $90 \%$. Out of the 10651481 persons living on the territory which became subject to new jurisdiction, 3221003 were of Hungarian ethnicity. This is less than $30 \%$. Who had been and who remained members of the Hungarian nation, then?! Data source: Tóth Pál Péter (1997:29)

14 http://www.allampolgarsag.gov.hu/index.php?option=com_content\&view=article\&id= 142: semjen\&catid $=43$ :torveny\& Itemid $=72 \quad(2014-07-26)$ 
cultural) identity of Hungarians within their home (neighbouring) country."15 In contrast, the introduction of preferential naturalisation in 2010 and the extension of voting rights in 2013 to those who do not and never did live in Hungary invokes the image of a country/people/nation, which is based on tribal, blood-based and historical fantasies.

Moreover, - as I will show soon -, somewhat contradicting the essential content identified above, the actual rules reflect an imperial attitude, not based strictly on descent and blood, but aimed at creating the maximum pool of faithful subjects, whatever their ethnic origin.

Being aware of this, let us have a brief look at the preamble of the Act on the election of members of parliament. ${ }^{16}$ This identifies as its foundations "Hungary's legislative traditions based on popular representation", guarantees that "in Hungary the source of public power shall be the people, which shall primarily exercise its power through its elected representatives", claims to ensure "the right of voters to universal and equal suffrage as well as to direct and secret ballot" and recognises minorities living in Hungary as "constituent parts of the State". Finally it surprises its readers versed in political philosophy with the following statement: "Hungarian citizens living beyond the borders of Hungary shall be a part of the political community". Let us reconstruct the underlying logic! Popular representation must refer to the representation of the people. The people are the source of popular power. Who constitute the people? They are those who exercise their power through their chosen representatives (i.e. the electorate). So the "people" include at least half a million persons who do not live in Hungary. The people stretch beyond the territory. But if that is the case, what kind of popular power do they exercise? What kind of legislative traditions support this constellation, if not imperial ones? (As a matter of fact, never in the history of Hungary were people living abroad entitled to vote. Even many of those who lived within the borders were excluded for quite a long time, whenever census was applied.) If the Hungarians living beyond the borders are "part of the political community", then what makes it political? Certainly 'the community' in this case is not a community which legislates for itself and exercises power over itself, as those living abroad are not bound by most of the laws adopted by their representatives, neither do they participate in social service schemes (health care, pensions, etc.).

15 Paper containing the position of the Hungarian government in relation to the act on Hungarians living in neighbouring countries CDL (2001) 80 Strasbourg, 21 August 2001. (2.13 point)

16 Act CCIII. of 2011. on the election of members of parliament 
The political community consists of those who are entitled to participate in the political process and are subject to the results of those processes. The political community forms the basis of a legal system. This community organises and controls its social, economic, and cultural life, and deals with its security concerns through the rule of law. The legal order separates friend and foe, fixes social development goals, and reflects the community's perceived role in the regional and global processes.

These conditions do not apply to persons who have continuously lived abroad, indeed perhaps have even been born there. Whereas those who may be away for a few years may still link their individual fates to the country (temporarily) left behind and so have a moral claim to participate in the exercise of the popular will (in the same manner as foreigners settled in a locality are entitled to participate in local elections precisely because they are affected), transforming the cultural-ethnic relationship into a public law nexus without sharing the public burdens and without the condition that those nationalised are directly affected is incompatible with the role of nationality in a democratic legal order (Similarly: Pogonyi, 2011: 696-700).

Let us now return to the imperial character of the whole setup! The construction after the amendment of the law on electing members of parliament does not rely on an ethnic-cultural nation. In essence, it reflects the thinking of the Austro-Hungarian Empire, or in general that of the empires of the $19^{\text {th }}$ century. It does not entitle to preferential naturalisation those who are Hungarians (assuming that the term "being Hungarian" may meaningfully be operationalized), neither does it entitle to preferential treatment those who declare themselves Hungarian as a gesture of self-identification. Rather it entitles to preferential naturalisation those whose ancestors were Hungarian nationals, or who can show in all probability that they descend "from Hungary" and can show their Hungarian language knowledge. ${ }^{17}$ At the time of the Trianon peace treaty that concluded the First World War, out of the more-than ten million former Hungarian nationals who found themselves under foreign jurisdiction after the borders were redrawn, less than a third were ethnic Hungarians. Nevertheless, the descendants of all the ten million are entitled to preferential naturalisation if they speak a bit of Hungarian. If the seven million non-Hungarians of 1920 have at least fourteen million descendants today, then more people without any link to Hungarian ethnicity or culture are entitled to preferential naturalisation than the whole present

17 Act LV. of 1993on Hungarian nationality section 4, para (3).. According to para (3a) the spouse (of whatever background) of the preferentially-naturalised person can also be so naturalised after ten years of marriage. If they have a child between them, five years are enough. 
population (9,7 million) of Hungary. To show that this is not a far-fetched interpretation of the law, let me quote again the deputy prime minister who when submitting the bill tried to show that it was not ethnically-oriented and did not prefer the Hungarian ethnie:

"The Act would be discriminative if it contained ethnic differentiation. This Act does not contain ethnic differentiation. If, for example a Saxon person from Brasov, whose ancestor originates from the Hungarian Kingdom and who speaks at some level Hungarian feels that she has to adhere to Hungarian traditions, to the heritage of Transylvania, to Hungarian culture, then she shall not be excluded from the option to acquire Hungarian nationality if she so requests. There is no ethnic discrimination so [the Act] does not conflict with any EU prescription." 18

The construction is scary: there is no ethnic preference in words, nor in the formal rules: language knowledge and imperial descent - these are the requirements. Let us project this situation onto Great Britain: whoever has an ancestor who was a British subject, or who can make it be believed that she originates from the British Empire and speaks a bit of English could be entitled to preferential naturalisation. What a colourful crowd could apply to become British nationals - presumably about one and a half billion people!

In reality, this is not what the force that governed the hand of the legislator wants. This fact is graphically illustrated by the words of deputy state secretary Gyula Budai, uttered at a naturalisation ceremony in Subotica, Serbia:

"Our fellow nationals beyond the borders are members of our nation, on an equal basis with those who live in Hungary. They are exactly the same Hungarians, speak the same language, preserve the same culture and are nationals of the same GreatHungary, which once existed."19

The confusion could not be more profound. Words of warning come handy in such moments:

"It is an old teaching: what should be the first deed of those who start to govern? The answer: the restoration of the right use of

18 http://www.allampolgarsag.gov.hu/index.php?option $=$ com_content\&view $=$ article\&id= 142: semjen\&catid $=43$ : torveny \& Itemid $=72 \quad(2014-07-26)$

19 "A nyelv ismerete alapvető feltétele a magyar állampolgárság megszerzésének." (Knowing the language is a basic condition of acquiring Hungarian nationality. Report from Vojvodina Television. Published on 21 February 2013. http://www.youtube.com/watch? $v=a 8 z z z v b o X o E$ (2014-05-19) 
words. If the use of the words is improper then the meaning of the thoughts is murky. If the meaning of the thoughts is murky then one cannot act accurately." 20

The right use of the words would require the acceptance of the following:

The cultural-ethnic-historic "nation" - if the term "nation" may carry a definite meaning at all - is not limited to the totality of nationals. It includes those who live beyond the borders or scattered around the world and have a Hungarian identity. For the sake of this statement identity merely refers to the fact that they consider themselves (at least partly) Hungarian, although being the nationals of another state.

The set of Hungarian nationals, in contrast, may include persons whose ethnic-cultural identity links them to another nation. However, they are part of the Hungarian body politic; they belong to the people that exercise supreme power.

The total number of Hungarian nationals born abroad (or living there) is approximately 3-4 million, who may well ignore their Hungarian nationality. They only qualify as Hungarian nationals because of the ius sanguinis principle, but for all practical purposes they consider themselves nationals of another state. The Hungarian authorities can neither identify nor localize them as no register is kept of these nationals. Still, by the force of law, all of them are entitled to contact any Hungarian consular representative and demand the issuance of a certificate of Hungarian nationality.

The body politic, the political community, is normally made up of the voting nationals who live in a country. They (together with non-voting family members) are bound together by a common historic venture, they recognise each other's equality and equal dignity even if they have competing political visions and consequent aspirations concerning the public good. These aspirations are always aimed at the long-term well-being of the whole community (the civic nation), not only at realising the particular interests of the given political actor.

The present public law situation does not meet this description of the political community. The constituency neither coincides with all the nationals, nor with those persons who (permanently) live in Hungary and so form the Hungarian society. This lack of a match between the legal situation and the meaningful understanding of a political community is the result of the following facts:

- The descendants of the Hungarian nationals who left the country after

20 Speech of Viktor Orbán at the meeting electing him prime minister, 10 May 2014, Hungarian Parliament. 
1929 did not lose their Hungarian nationality with the passing of time or remoteness in generational terms. Ius sanguinis is not limited in its operation. Therefore formally all these persons are members of the civic nation in the sense that they are entitled to exercise their rights. However, the lack of any evidence of their Hungarian nationality and their total ignorance of this option practically paralyses them. The state makes no steps to inform them or bind them to the country, nor do they wish to have meaningful, "genuine and effective" links to it.

- The constituency is not limited to people living in Hungary, as the recent legislation has opened the way to Hungarian nationality and to partial electoral rights for those whose ancestors were Hungarian nationals, even if they were not born Hungarians. In their case the operation of the ius sanguinis principle was interrupted either by the post First World War arrangements accompanying the transfer of the territory, or by the Socialist period, when dual nationals had to choose one and terminate the other. After 2010, these persons - as already mentioned above - could apply for Hungarian nationality through a simplified procedure, and with it they got the right to participate in national elections (namely, in list voting, without the right to vote in any individual electoral district).

- Foreigners who have settled in Hungary and who have permanent residency (approximately 220 thousand persons) are not entitled to participate in either parts of the national election (list or district voting), no matter how many years or decades have they shared our fate, no matter that they participate in sharing the public burden. They are excluded from the body politic, from the concept of the people exercising popular power, even if the laws bind them equally with others.

The right use of words has shown that behind the slogan of "unification of the nation", in fact one finds the building of an empire, the construction of a clientele (Waterbury, 2010). The actual effect of extending the opportunity for naturalisation, accompanied by voting rights, is the creation of a pool of loyals; a voting base which recognises the divine delegation of the leader who has been brought on the wings of eagles to govern his subjects in the right direction, for which he is only grateful to God. Sounds out of date? Listen to the words of Viktor Orbán, presently prime minister of Hungary, spoken as part of his inauguration speech in the Hungarian Parliament on 10 May 2014. "Respected House! We have to serve, so that the state-structure and the government which frame the common life of the nation be constantly animated by soul, goal and sense, be always determined by the knowledge of and responsibility in the common fate. With all my strength I want to serve this command. I beg the Good Lord that, if he has brought me that far, if he 
has carried me on eagle-wings, then he strengthens me, in order to be able to meet the responsibility awaiting me. I beg that my acts be always governed by faith and insight. Soli Deo Gloria - Glory to God alone."

Two related questions arise: 1. May a Prime Minister become such out of the grace of God - thereby borrowing the legitimacy argument employed by absolute rulers?; 2. If the frame of the nation is the "state structure", then where is the place of the Hungarians who live beyond the borders? Is there a duplication of the state, and beyond the internationally-recognised Hungary is there a shadow "Large Hungary" that incorporates the Hungarian nationals who live in other states like Romania, Ukraine or Serbia? Or does the term "state structure" only denote the machinery that works within the borders, so the Hungarians beyond them do not form part of the nation? Does it mean that their real role is limited to assuring that power remains in the hands of the leader, who enjoys the goodwill of God?

\section{ON THE MYTH OF EQUALITY OF NATIONALS AND OF THEIR RELIABILITY}

Contrary to all other claims, Hungarian nationals in fact do not have one set of equal rights. While protagonists of naturalisation on a preferential basis stress that there are no two different classes of nationals, in fact there are several classes of Hungarian nationals.

The table below does not show all the entitlements (rights) and all the reference bases. Still, it unequivocally proves that the Hungarian legal order - and the political force behind it - creates at least five different classes of Hungarian nationals, ${ }^{21}$ and allocates them different benefits and drawbacks. Or, to put it in a more neutral way, it provides different opportunities in fundamental matters such as taxation, national defence, and forming the popular will.

21 More classes could be formed. Health minister regulation 59/2007. (XII. 29.) EüM on the support of the health care of Hungarians living beyond the border only covers "persons living in the Serbian Republic or Ukraine and declaring themselves to be Hungarian" irrespective of whether they are Hungarian nationals or not. This is a clear differentiation between Hungarian nationals who live in those countries and those who live beyond the borders, but in other countries. The Act on national higher education (Act No CCIV of 2011) permits students who come from the countries where the Status law is applicable to work in their countries of origin, instead of Hungary, if they were educated without having to pay a tuition fee. All other Hungarian nationals must work in Hungary a given number of years in exchange for the tuition-free education, no matter where their residence is. 
Table 1 Different classes of Hungarian nationals

\begin{tabular}{|c|c|c|c|c|}
\hline & Benefit/privilege & $\begin{array}{l}\text { Remark / base of } \\
\text { comparison }\end{array}$ & Drawback & $\begin{array}{l}\text { Remark / base of } \\
\text { comparison }\end{array}$ \\
\hline $\begin{array}{l}\text { Hungarian } \\
\text { Nationals (HN) } \\
\text { living in Hungary }\end{array}$ & $\begin{array}{l}\text { May vote in } \\
\text { national elections } \\
\text { in individual } \\
\text { districts }\end{array}$ & $\begin{array}{l}\text { HN living abroad, } \\
\text { without an address } \\
\text { in Hungary }\end{array}$ & $\begin{array}{l}\text { Military labour } \\
\text { obligation } \\
\text { Civic defence } \\
\text { obligation } \\
\text { Personal income } \\
\text { tax payment }\end{array}$ & $\begin{array}{l}\text { HN without } \\
\text { Hungarian } \\
\text { address, living } \\
\text { abroad }\end{array}$ \\
\hline $\begin{array}{l}\text { HN living } \\
\text { abroad, but with } \\
\text { a Hungarian } \\
\text { address }\end{array}$ & $\begin{array}{l}\text { May vote in } \\
\text { national elections } \\
\text { in individual } \\
\text { districts } \\
\text { No payment of } \\
\text { personal income } \\
\text { tax if outside } \\
\text { country for more } \\
\text { than } 183 \text { days in } \\
\text { the given year }\end{array}$ & $\begin{array}{l}\text { HN without } \\
\text { an address } \\
\text { in Hungary, } \\
\text { including those } \\
\text { naturalised on a } \\
\text { preferential basis } \\
\text { (NPB) } \\
\text { HN (and } \\
\text { foreigners) living } \\
\text { in Hungary and } \\
\text { earning income }\end{array}$ & $\begin{array}{l}\text { Voting in the } \\
\text { national elections } \\
\text { only personally } \\
\text { at Hungarian } \\
\text { representations } \\
\text { abroad. Voting by } \\
\text { mail not possible }\end{array}$ & $\begin{array}{l}\text { HN living abroad } \\
\text { without an address } \\
\text { in Hungary, } \\
\text { including NPB }\end{array}$ \\
\hline $\begin{array}{l}\text { HN appearing } \\
\text { in a Hungarian } \\
\text { registry, but } \\
\text { without an } \\
\text { address in } \\
\text { Hungary = NPB }\end{array}$ & May vote by mail & $\begin{array}{l}\text { HN living in } \\
\text { Hungary / HN who } \\
\text { has an address in } \\
\text { Hungary }\end{array}$ & $\begin{array}{l}\text { May only vote } \\
\text { on the national } \\
\text { list but not for } \\
\text { candidate in } \\
\text { individual district }\end{array}$ & $\begin{array}{l}\text { HN living in } \\
\text { Hungary, or living } \\
\text { abroad but with a } \\
\text { Hungarian address }\end{array}$ \\
\hline $\begin{array}{l}\mathrm{HN} \text { in general, } \\
\text { including those } \\
\text { not appearing } \\
\text { in any registry, } \\
\text { but with a } \\
\text { certificate of their } \\
\text { nationality }\end{array}$ & $\begin{array}{l}\text { May hold public } \\
\text { office } \\
\text { Is entitled } \\
\text { to consular } \\
\text { protection } \\
\text { May settle in } \\
\text { Hungary and } \\
\text { the EU } \\
\text { Has a right to } \\
\text { education }\end{array}$ & $\begin{array}{l}\text { Immigrant } \\
\text { foreigner }\end{array}$ & $\begin{array}{l}\text { Must die in } \\
\text { the defence of } \\
\text { Hungary } \\
\text { Excluded from } \\
\text { elections }\end{array}$ & $\begin{array}{l}\text { Immigrant } \\
\text { foreigner } \\
\text { HN living abroad } \\
\text { but appearing in } \\
\text { a registry or with } \\
\text { an address in } \\
\text { Hungary }\end{array}$ \\
\hline $\begin{array}{l}\text { Latent } \mathrm{HN} \\
\text { who has a right } \\
\text { to acquire } \\
\text { certification } \\
\text { of Hungarian } \\
\text { nationality }\end{array}$ & $\begin{array}{l}\text { May become an } \\
\text { EU citizen any } \\
\text { time }\end{array}$ & $\begin{array}{l}\text { Third country } \\
\text { (non-EU) national }\end{array}$ & $\begin{array}{l}\text { Practically no } \\
\text { rights attached } \\
\text { to nationality. } \\
\text { (including the } \\
\text { right to return) } \\
\text { can be exercised } \\
\text { before the } \\
\text { certificate is } \\
\text { acquired }\end{array}$ & $\begin{array}{l}\text { Third country } \\
\text { immigrants in } \\
\text { Hungary. } \\
\text { HN living in } \\
\text { Hungary or } \\
\text { abroad, with a } \\
\text { document proving } \\
\text { HN }\end{array}$ \\
\hline
\end{tabular}

The recognition of the different categories of Hungarian nationals has become a textbook truth and is recognised by the teaching material used at the National University of Public Service (Cserny 2013:139). The admission of the different classes is not accompanied by a detailed explanation, and the 
feeble efforts that are made to explain the differences are less than convincing. When addressing the difference between the voting rights of Hungarians living in Hungary and those living abroad without a Hungarian address, it notes

"The existence of the two categories is unfortunate. Nevertheless such limitation on the voting rights of those living abroad may be considered proportionate and justifiable, as they do not share the everyday life, therefore it is not certain that decisions of the Parliament affect them in the same way as those living within the borders. However, they still have the option to influence public matters" (Cserny, 2013:140).

Let us take seriously - no matter how difficult it is - the textbook from which future public officials learn! Close reading reveals the following:

1. The deprivation of a Hungarian national who has no address in Hungary from the right to vote in an individual district may be proportionate and justifiable. Or it may not. The text does not go as far as to state that it is justifiable, which reveals serious concerns/inconvenience on the part of the author.

2. What could the possible justification be? "Living the everyday life" and being affected by the decisions of the Parliament? I fully agree with this criterion. Those people who take part in the life of a community should be considered members of the political community which governs itself through its elected Parliament. But: settled foreigners (immigrants) meet these criteria as well! Consequently, they should also have voting rights in the national elections as they are also part of everyday life and are bound by Hungarian laws. They also belong to the people of the country. The textbook does not consider this "side effect" of its argument.

3. Those living beyond the borders "still possess the option to influence public matters". Justification (determining what militates allowing them influence) is replaced by the repetition of the fact that they are entitled to influence public matters. If the (unrevealed) justifying factor is the fact that some Parliamentary decisions affect them, then nearly seven billion people could be entitled to vote, as some decisions of the Hungarian legislator (e.g. visa rules, taxation regulations, etc.) affect every human being.

The myth of the equality of the nationals is sibling to the belief that fellow nationals are more trustworthy (reliable) than foreigners. In the seventieth year of the Hungarian holocaust, when once again news about book-burning surfaced, in a year when elections to the European Parliament propelled 
more far right MPs into the ranks than ever before, in a year when Ukrainian nationals are attacking each other with machine guns, tanks and air forces, perhaps we may justify questioning the fiction that fellow nationals are more trustworthy than foreigners.

Nevertheless, the Hungarian legal system - as with many other legal orders - has abundant rules which exclude third country nationals and EU citizens from certain professions. Here is a quick and incomplete list: president of the republic, government official, most of the public officials, judge, prosecutor, armed security guard, wildlife guard, member of the forestry service, professional hunter, fisheries guard, public space controller. ${ }^{22}$ The question, "Why should a Hungarian Christian democrat trust a Hungarian Nazi more than they should an Austrian Christian Democrat?" cannot be answered. Why could the latter not guard our forests or banks? Why could a person with a Hungarian law degree but British nationality not serve as a better judge than his Hungarian counterpart? There is no response which goes beyond superstition. All conceivable answers go back to tribal allegiance, blood community, extended family of the deep past, our predestined fate. But it should be borne in mind that our "common fate", our history, could be read as a history of being divided among ourselves. Start with Máté Csák, the selfappointed landlord and ruler of large portions of the country in the 13 and 14th centuries. Continue with Ferenc Rákóczi's fight against the king in the 18th century, and then the 1848-1849 revolution, the commune in 1919, the Nazi takeover in 1944, the 1956 revolution and so on. Hungarian fate can be read as an endless chain of oppositional activity, the incessant perpetuation of adversarial movement. In fact there are few nations whose history is free from civil wars, insurgencies, or bitter infighting.

The thesis according to which the fellow national is more trustworthy than the foreigner is politico-philosophically an overgeneralisation, if the opposite cannot (is not allowed to) be proven. Nor is this contention supported by history. Regretfully, it reflects the enemy-creating mentality which makes the holding of dual nationality so suspicious and which probably goes back to the French revolution that led to the setting up of popular armies, thereby making enemies of the whole (male) population of an opposing country.

22 Before Hungary's accession to the EU Judit Tóth composed a list of 44 lines specifying functions/jobs which could only be perfomed by Hungarian nationals. Tóth (2014:48 -50). 


\section{THE SUSPICIOUS FOREIGNER}

The ethnicising, blood-based and trust-requiring conception of nationality leads to the perception of the nationals of another nation with which the given state is at war as enemies, even if those persons have deep roots in the country of residence; for example, through their local families.

Perhaps stored in the deeper layers of memory, and worth recalling, is that during the First World War both the Central Powers and the Entente interned civilian nationals (men) of the other side. In 1918, in Germany, more than 100000 foreign civilians (not prisoners of war!) were detained. The Austro-Hungarian Monarchy kept approximately an equal number of Serbian nationals under its control, and France interned more than 60000 enemy civilians. Great Britain was not hesitant either in this regard: as early as in November 1915, 32440 German, Austrian and Hungarian civilians had been detained (Stibbe, 2006: 7-8). Czarist Russia had more than 300000 enemy civilians in detention by the end of 1917. (Stibbe, 2006:8)

An infamous event in the Second World War was the internment of Japanese, Germans, and Italians living in the United States. Based on the decisions of President Roosevelt, several thousand persons were interned, including many who were nationals of the United States. ${ }^{23}$ Not only were 31000 "enemy aliens" confined to designated places, but the US also offered to allow Latin American states to send enemy aliens from their territory to the US. This led to the transfer of 6600 persons from fifteen Latin American states. ${ }^{24}$ The number of US nationals with Japanese backgrounds who had to sell their possessions and move to remote, designated places was even larger; it exceeded 100000. The large scale internment of the Japanese shows the dangers of the ethnicisation of nationality. Ethnicity and legal status merge and either of them is enough to make a person a target of discriminative treatment. In 1988 Congress adopted Statute No. 100-383 in which it acknowledged "the fundamental injustice of the evacuation, relocation, and internment of United States citizens and permanent resident aliens of Japanese ancestry during World War II."

Collective stigmatisation has not ceased with the taking hold of human rights after 1945. Three years after the US had apologised for injustices committed against the Japanese population, the United Kingdom took measures against "enemy nationals", albeit this terminology was not used. During the 1990-

23 US national Archives: Brief Overview of the World War II Enemy Alien Control Program http://www.archives.gov/research/immigration/enemy-aliens-overview.html (2014-07-26)

24 Ibid. 
1991 Iraqi-Kuwaiti conflict around thirty people were held as prisoners of war because they were considered to be active or reserve members of the Iraqi $a^{a r m y}{ }^{25}$, and more than a hundred Iraqi nationals and nationals of other Arabic states - who were not involved in the conflict - were expelled and detained with a view to removal (Walsh, 1998).

The UK procedure differed from those of the two World Wars as it affected significantly fewer persons and, formally, was an alien police procedure conducted against individuals whose "departure from the United Kingdom would be conducive to the public good for reasons of national security" (Walsh, 1998:268-269). Still, the closed procedure, the withholding of relevant information, and the non-judicial nature of the review has led commentators to conclude that the struggle between the rule of law and the logic of securitising was won, once again, by the latter (Walsh, 1998: 289 -292 , with further references).

\section{THE CHANGING ASSESSMENT OF DUAL NATIONALITY}

"Dual nationality is an undesirable phenomenon, detrimental both to the friendly relations between nations and the well-being of the individuals concerned," wrote Bar-Yaacov in his monograph on dual nationality in 1961 (Kochenov, 2010:6 quoting Bar-Yaacov, 1961). This thought has prevailed among the views on nationality practically since the birth of nationality rules created in the wake of nationalist movements (Howard, 2005:700-702; Pogonyi 2011: 685,688). The 1963 "Convention on the Reduction of Cases of Multiple Nationality and on Military Obligations in Cases of Multiple Nationality" adopted under the aegis of the Council of Europe ${ }^{26}$ in its preamble, exposed the justification for the convention states:

"Considering that cases of multiple nationality are liable to cause difficulties and that joint action to reduce ... the number of cases of multiple nationality ... corresponds to the aims of the Council of Europe."

Article 1 prohibited dual or multiple nationality in the cases when a person of full age acquired by her own free will, by means of naturalisation, option or recovery, the nationality of another state party. The state whose nationality the person had possessed was not entitled to permit the retention of that

25 The number has changed in light of successful review procedures.

26 Strasbourg, 6 May 1963, ETS, 043 
nationality. The Protocol of 1977 attached to the convention did not challenge that and the 1963 treaty is still in force. Only four parties to the convention have changed their minds since 1963 and have withdrawn from this obligation, in accordance with the convention. ${ }^{27}$ The second protocol to the convention was adopted in $1993^{28}$, and in narrowly-defined cases (migration to the naturalising country, marriage, etc.) permitted dual nationality, but still prohibited the extension of a second nationality to a person who did not move to the naturalising state.

A change in the approach to dual nationality was brought by the 1997 "Convention on Nationality" 29 of the Council of Europe. This new text obliged state parties to accept dual nationality in a narrow set of cases, in line with the 1993 Protocol to the 1963 Convention. These cases are: when the child by her birth, ex lege becomes a dual national (Article 14 § (1) a); and when concluding a marriage automatically entails the acquiring of the new nationality, without losing the existing one. In all other cases this convention also entitles the state to deprive of nationality those who - like in cases of naturalisation in the simplified procedure - voluntarily acquire a new nationality (Article $(7 \S$ (1) a)). Exactly this provision was invoked by Slovakia when, as a retorsion to the preferential naturalisation introduced by Hungary, it changed its law on nationality and threatened all those who voluntarily acquired a foreign nationality with deprivation of their Slovak nationality. ${ }^{30}$

The more relaxed approach to dual nationality does not reflect a weakening of the myth according to which the fellow national is more trustworthy than the foreigner. Rather, it is the result of the increased impact of human rights. It reflects a more robust respect for the equality of the sexes (and genders), family life, and individual self-determination, and it also serves to smoothen political and practical links between the migrants' country of origin and their new home, as is exemplified in the German-Turkish context.

27 Belgium (2007) France (2008) Italy and Luxembourg (2009) List of declarations made with respect to treaty No.043 http://conventions.coe.int/Treaty/Commun/ListeDeclarations. asp? $N T=043 \& C V=1 \& N A=12 \& P O=999 \& C N=999 \& V L=1 \& C M=9 \& C L=E N G(2014-07$ 26) Of the twelve parties only Germany has withdrawn completely from the convention.

28 Second Protocol Amending the Convention on the Reduction of Cases of Multiple Nationality and Military Obligations in Cases of Multiple Nationality, Strasbourg, 2 February 1993. ETS. 149. It only has two parties.

296 November 1997, ETS No. 166.

30 National Council of the Slovak Republic, Law No. 40/1993. on nationality in the Slovak Republic. (13 January 1993.) The deprivation of nationality was introduced by Law No. 250/2010 T.t. following a decision of the Slovak Parliament of 26 May 2010. For comment, see: Gyeney (2013:163-165). 
At a rhetorical level many nationality rules still require faithfulness to the country, its defence, and the treatment as (personal) enemies all those whom the political leadership deem to be enemies. ${ }^{31}$

All this leads to the conclusion formulated by Christian Joppke that nationality law is following a bifurcated path. One tries to make the relations between the national and the state "thick", "real" and substantive, impregnating the legal bond with socio-cultural elements, and the other accepts a "light" notion of nationality according to which differences between nationals and settled foreigners, or at least between a national and a national of a member state of a group of integrating states (EU, Nordic Union, the Benelux Union) are gradually disappearing (Joppke, 2010:12-19.)

This duality enables the official discourse about preferential naturalisation. That discourse presents the Hungarian nationality as a thick one, reflecting fidelity and belonging, a legal and political bond that forms and reflects personal identity. At the same time it trivialises the other nationality of the dual national and assumes a much less intense relationship with that other state. In that context, no mutual trust and commitment is assumed.

\section{VISA AS STIGMA}

Making access to dual nationality easier generates the impression that states look at foreigners with less suspicion. This illusion is defeated by the international visa system which is the most developed regime for collective stigmatisation. Making entry dependent on an individual permit (the visa) is a consequence of the First World War that made whole peoples into enemies (Torpey, 2000: 111-116). Thus, the freedom of travel and immigration, which prevailed almost everywhere before 1914 , ceased to exist. ${ }^{32}$ Nationals of the enemy states could no longer travel according to their whim, as contemporaries of Tolstoy or Geothe and even before them the lads on their way to becoming masters of a profession or students attending foreign universities in the

31 A perfect illustration is offered by the Hungarian oath of nationality “...I swear that I consider Hungary my home country, I wll be a faithful national of Hungary, will respect and obey the Fundamental Law and the Laws. I will defend my home country according to my strength and serve it according to my capabilities". Fidelity, fight, service... What if the other nationality expects the same? What should dual nationals in Crimea or Eastern Ukraine do? On which side of the barricade should they show up?

32 Limitations on immigration were introduced by the United States in the second half of the 19 th century and, naturally, freedom of immigration did not apply in the closed Asian empires. 
medieval ages could. ${ }^{33}$

Today the US waives visa obligation for the nationals of 37 states and for the inhabitants of Taiwan. ${ }^{34}$ This list of preferred states even excludes some EU member states, namely Bulgaria, Croatia, Poland and Romania. The list includes the remaining EU members and of all the other countries only six states/territories, each of which have more than 6 million inhabitants: Australia (23 million), Chile (18), Japan (128), South Korea (50), Switzerland (8), and Taiwan (23). Consequently, more than six billion persons can only admire the Statute of Liberty if they receive an individual permit to do so. Otherwise, they do not have the liberty to go there. ${ }^{35}$

In the spring of 2014, the EU list of states the nationals of which did not need a visa to enter contained 38 states and 3 territories (Hong Kong, Macau, Taiwan) ${ }^{36}$ Considering that the $28 \mathrm{EU}$ member states may be added to these 38 , the list is more generous than that of the US. Nevertheless, it still excludes most of the developing world, including China, India and most of SubSaharan Africa, and only exempts from the obligation some Latin-American countries.

Looking at the larger picture, one may note that, on average, nationals of OECD countries were visa-obliged in only 93 states in 2006, and nationals of non-OECD countries in 156 (Neumayer, 2006:78).

What justifies the issuance of a visa, the requirement for which largely did not exist before the 20th century? More precisely: how do states, which introduce visa obligations against persons seen as pawns in a game, or considered a threat, justify their introduction? Justification normally starts from the idea of collective sanction (punishment) or collective stigmatisation. The punishment argument is directed against the government of the visa-obliged population. The visa-introducing state opposes the policy of the given government and, in retaliation, forces the population of the country to apply for a (wilfully deniable) visa. The requirement of a visa in these cases serves as a foreign

33 Obviously neither serfs bound to the land and their landlords nor the very poor could utilise this freedom. But that does not deny its legal existence.

34 http://travel.state.gov/content/visas/english/visit/visa-waiver-program.html\#countries (2014-07-26.)

35 The champions of exclusion are authoritarian states such as North Korea and Saudi Arabia. Similarly, the Socialist states required visas of everyone except nationals of other socialist states.

36 Council Regulation (EC) No 539/2001 of 15 March 2001 listing the third countries whose nationals must be in possession of visas when crossing external borders and those whose nationals are exempt from that requirement (OJ L 81/1., 21.3.2001). Annex II. as amended. 
policy tool (Meloni, 2006:37). The visa becomes a collective stigma when it is based on the presumption that the whole population of the visa-obliged country constitutes a threat, either from a national security point of view, or as potential illegal immigrants. That sort of visa collectively stigmatises the not-yet-entered many for the deeds of the few fellow nationals who may have violated the rules of the destination country (Meloni, 2006:40).

This three-pronged approach (foreign policy, security threat, and illegal immigration) characterises EU visa regulation: "The determination of those third countries whose nationals are subject to the visa requirement ... is governed by ... a variety of criteria relating inter alia to illegal immigration, public policy and security, ... the European Union's external relations with third countries, consideration also being given to the implications of regional coherence and reciprocity." 37

What is wrong with the justification of the visa obligation (Guild, 2003:9297)?

1. On the basis of the actions of a few it makes everyone a subject of suspicion and a victim of collective punishment (the visa). At the root of this usually there is nothing more than unreliable statistics and selffulfilling prophecy. The number of visas denied should be an index of the scale of the danger of illegal immigration, but the cause for denying a visa is the anticipated illegal immigration itself. In other words, it is not the number of undocumented immigrants who are actually caught which triggers the visa obligation, but the fact that, fearing illegal immigration, authorities a priori deny them a visa - which obviously leads to a large number of denied visas, which in turn "proves" the danger of illegal immigration. A classical vicious circle. ${ }^{38}$

2. Visa requirements used in interstate relations in order to promote political goals unrelated to migration affect the whole population. The population becomes prisoner of a political confrontation, a pawn in a chess game. If the authoritarian political system is the target, the innocent population bears the brunt. To exacerbate matters. if the political opponent is the opponent of an EU member state, then the common visa list excludes the affected people not only from the relevant EU member state, but from all, (with the potential exception of the UK and Ireland which pursue

37 Council Regulation (EC) No 539/2001 of 15 March 2001 listing the third countries whose nationals must be in possession of visas when crossing external borders and those whose nationals are exempt from that requirement (OJ L 81/1., 21.3,2001), preamble, paragraph (5)

$38 \mathrm{See}$, for example, the infamous regulation of the US which is based (partly) on the 'proportion of visa denials' from all visa applications. 
independent visa policies). On the other hand, the exclusion extends to Iceland, Liechtenstein, Norway and Switzerland as they joined the common regime in order to become part of the Schengen area without internal border controls.

3. The visa requirement is an ill-conceived tool for maintaining national security or public order by threatening people out of the territory. If individuals are known threats, their entry may be denied - even if otherwise they would not need a visa. Border control agents can keep them out, or arrest them if they are silly enough to try entering a country as a known threat. The SIS II system in the EU and the different national registers of undesirable immigrants serve this purpose. If an individual has not yet been identified as a national security threat, then the visa procedure will not reveal it, as those with menacing intent can create perfect covers for themselves.

4. The visa requirement prevents asylum seekers from reaching safe territories.

5. To exacerbate matters the visa requirement is not effective in respect of its main goals. ${ }^{39}$

Let us address the above five critical remarks!

There are no reliable statistics about the nexus between the efficiency of the visa policy and the number of undocumented migrants. But it is a trivial fact that the majority of migrants who become illegal have arrived legally (with a visa, or as visa-free travellers) and become illegal by way of overstaying or changing their status (for example, by taking up employment while having arrived under the rubric of "student") (Neamayer, 2006:74, Frontex, 2014:52). In the European Union the number of illegal migrants that are caught is more greatly influenced by whether one has to flee their country of origin or not, and whether asylum seekers are statistically registered as illegal migrants. In fact, the number of illegal migrants has decreased for the last five years (Frontex, 2014:72, Statistical Annex, Table 4).

The introduction of a visa obligation as a foreign policy tool in essence deprives the population of the target country of their identity as private individuals and identifies them only as members of a political community, a community that, as a whole, is perceived as threatening. This was the case (twice) when Canada restored visa requirements for Czech nationals because

39 Reasons for denying visas by EU member states are not published. In $20124,8 \%$ of all C-type visa applications were refused. The range was large: for Algeria denials amounted to $27 \%$ of all applicants, in the case of Iran it was $8 \%$, whereas less than $1 \%$ of Russian and Belorussian applicants got a negative response (Frontex, 2014:17). 
of the large number of asylum requests from Czech Roma (and did the same once and threatened to do the same again for Hungary). All the nationals of the Czech Republic were punished (and all Hungarians were put under pressure) because of the undesirable acts of a few thousand fellow nationals who in fact committed no crime as applying for asylum is not an offence (Tóth, 2013:38-40).

Protecting national security and public order with the help of visas is an illusion. Denial of a visa may screen out the pickpockets, the beggars, potentially illegal sellers or potential prostitutes, but the process is incapable of identifying the yet-unknown culprits of large scale terror attacks. Neither does it exclude the leaders of trafficking rings or drug smuggling cartels. These persons can easily meet the visa requirements: they will have return air tickets, hotel reservations, and available financial resources. ${ }^{40}$ They will only be caught if it is known from other sources that they pose a danger. This bitter lesson was learned in September 2001. All the terrorists involved had visas or valid residence permits.

Most critical is the nexus between visa and asylum. Today, the Syrian case painfully shows how visa obligations act as obstacles to safety. If they did not, then could it happen that out of 2,9 million refugees, only about one hundred thousand would manage to reach the European Union ${ }^{41}, 1.1$ million get to Lebanon, eight hundred thousand to Turkey, and six hundred thousand to

40 This is what the EU Visa Code (Regulation (EC) No 810/2009 of the European Parliament and of the Council of 13 July 2009 establishing a Community Code on Visas, OJ L 243/1, 15.9.2009) requires from the visa applicant in its Article 14:

(a) documents indicating the purpose of the journey;

(b) documents in relation to accommodation, or proof of sufficient means to cover his accommodation;

(c) documents indicating that the applicant possesses sufficient means of subsistence both for the duration of the intended stay and for the return to his country of origin or residence, or for the transit to a third country into which he is certain to be admitted, or that he is in a position to acquire such means lawfully, ...;

(d) information enabling an assessment of the applicant's intention to leave the territory of the Member States before the expiry of the visa applied for."

41 The figure is uncertain. Eurostat's figure for 2013 is 50470. (Asylum applicants and first instance decisions on asylum applications: 2013 Eurostat, Staistics in Focus, Table 2, page 5.). The UNHCR in July 2014 mentioned 123600 persons, admitting that the figure may be too large as some have submitted more than one application. "U.N. asks Europe to take Syrian refugees as region saturated" http://www.reuters.com/article/2014/07/11/us-syria-crisisrefugees-idUSKBNOFG1ZZ20140711 http://www.reuters.com/article/2014/07/11/us-syriacrisis-refugees-idUSKBNOFG1ZZ20140711 (2014-07-26) 
Jordan? Even Iraq is home to more Syrian refugees (two hundred thousand) than the EU. ${ }^{42}$

Visa, as a block on the road to safety was applied during the Southern Slav war. Austria restored the visa obligation against the Bosnians starting from 2 July 1992. Earlier, nationals of the Socialist Federal Republic of Yugoslavia could enter Austria visa-free (Nagy, 2012:142).

It is not denied that the abolition of a visa requirement may lead to a surge in asylum applications. Many of these applications for refugee status turn out to be unfounded - as happened after the EU abolished the visa obligation for Albania, Serbia and other Western Balkan states. ${ }^{43}$ However, this is not necessarily the case. The nationals of Latin America who got visa-free entry did not storm European refugee offices. Frequently, applicants who arrive visa-free from Serbia, Bosnia and Kosovo would in fact prefer to become long-term immigrants, not refugees. Many of them had lived in the country of application before and wished to return to the site of their refuge during the war in the Balkans. As regular immigration is foreclosed to them, they try the asylum route. That is a lose-lose situation, as dealing with the great number of unfounded applications demands resources which should be devoted to those fleeing actual persecution or other serious harm, and these applications inevitably end up being denied with the removal and long-term banning of the applicant from EU territory. Still, the solution is not to restore the visa obligation even if the possibility for this has been established, entitling the Commission of the EU to act. ${ }^{44}$ Rather, the appropriate response to an increasing number of applications is to create a fast and efficient procedure that can render decisions in such cases within days or weeks, as Sweden, Germany and Canada have done.

42 UNHCR: Inter-Agency Regional Response for Syrian Refugees Egypt, Iraq, Jordan, Lebanon, Turkey 6 - 12 July 2014, http://data.unhcr.org/syrianrefugees/regional.php\#_ga=1.1874141 20.1793988378 .1405419596

43 Of all the applications submitted by persons who could enter visa-free, 97\% (33000 applications) were submitted from the five states which were trasferred to the visa-free list in 2009 and 2011. (Albania, Bosnia-Herczegovina, FYRoM, Montenegro and Serbia) Frontex: Western Balkans Annual Risk Analysis 2014, Warsaw, 2014, 33

44 See point 2 of Article 1 of the 289/2013/EU regulation (OJ L 347/74, 20.12.2013) amending regulation 539/2001/EC listing the third countries whose nationals must be in possession of visas when crossing external borders and those whose nationals are exempt from that requirement. 
The stigmatising nature of the visa is most conspicuous in asymmetric bilateral situations, in which nationals of one of the partners are obliged to apply for visa and nationals of the other are free to enter. ${ }^{45}$

\section{DOMESTIC BURDENS OF NATIONALITY}

Nationality not only affords rights, it also entails obligations and puts limitations on one's freedom. This chapter will not cover those state regulations that put a burden on everyone under a jurisdiction - that is, nationals and foreigners alike - even if those commands may be criticised from a human rights point of view. So it will not address the French prohibition on wearing the niqab in public places as that ban is not French-nationality specific; it applies to foreigners under French jurisdiction as well. ${ }^{46}$ The following points are concentrated on rules which put a burden on a person because she is the national of the state. The same rules would not apply to resident foreigners.

Naturally, space limitations prevent the full listing of such targeted rules, and nor can we delve into the details. The aim is simply to highlight that nationality of a country may be a bitter gift.

\section{Compulsory military servvice}

Compulsory military service has been central to thinking about nationality. Perhaps it is the most important "duty of the national". Even at the time of the French Revolution people could be compulsorily drafted and pressed into military service. Nevertheless, it only became general practice before and during the "Great War" (i.e. at the end of the $19^{\text {th }}$ and the beginning of the $20^{\text {th }}$ centuries) (Csapody, 2005). Today it is on the retreat. Only a relatively small number of states still retain the institution of compulsory military service in peacetime, among them a few European states (Estonia, Finland, Russia, Switzerland, and Turkey).

45 Two examples: Hungarians do not need a visa to enter Tunisia, but Tunisians need one to visit Hungary. A similar assymetry is present in the US - Polish relationship. See further the Seventh report [of the Commission of the EU] on certain third countries' maintenance of visa requirements in breach of the principle of reciprocity. COM(2012) 681 final, Brussels, 26.11.2012.

46 The European Court of Human Rights (somewhat surprisingly) has found that ban compatible with the European Convention on Human Rights. Case of S.A.S. v. France, (Application no. 43835/11) Grand Chamber judgment of 1 July 2014. 
But, in times of military conflict most states still call upon their nationals (at least the men) to join the armed forces. Military duty entails participation in a civil war or in an international conflict. A soldier participating in an international conflict may perceive it as a "just war", a war in defence of the homeland, but this may also not be the case. A Russian soldier in Afghanistan in the 1980s or in Ukraine these days may very well distance himself from the political and military leaders' goals, but nevertheless - at least in Afghanistan - does (did) not have the choice of denying service.

The inferno of civil war can once again be witnessed, this time in Ukraine: Ukrainian nationals are killing Ukrainian nationals, many of whom are mobilised civilians who are sent to the front against their will. The same applied when ethnic Hungarians of Voivodina (Serbia) had to fight in Kosovo in the Milošević army against ethnic Albanians, all being nationals of (rump) Yugoslavia.

Fewer and fewer international conflicts are occurring. Their assessment depends on the political standpoint of the assessor. ${ }^{47}$ Military activity undertaken with the approval of the UN is legitimate. As far as I know, soldiers participating in these activities are either volunteers or professional servicemen, so their presence is not the fulfilment of a duty attached to nationality.

Whenever an international conflict unfolds and neither party enjoys the support of the UN, then the drafted soldier may find himself/herself in the military theatre against his/her will even if (s)he fundamentally opposes the action. Desertion amounts to treason and may swiftly lead to the death penalty meted out by a military tribunal. The only hope is that the international community will condemn the action of the state. This would entitle the person performing compulsory military service (or any military person under orders to commit a war crime or a crime against humanity) to refugee status - at least in the EU. ${ }^{48}$

47 Was the attack against Afghanistan (2001) and Iraq (2003), or the bombing of Yugoslavia (1999) agression?

48 Article 9 paragraph (2) point e) of the Directive 2011/95/EU of the European Parliament and of the Council of 13 December 2011 on standards for the qualification of third-country nationals or stateless persons as beneficiaries of international protection; for a uniform status for refugees or for persons eligible for subsidiary protection; and for the content of the protection granted. It explains that "persecution" may consist of "prosecution or punishment for refusal to perform military service in a conflict, where performing military service would include crimes or acts falling within the scope of the grounds for exclusion" [from refugee status]. UNHCRS' Handbook on Procedures contains a similar idea: "Where ... the type of military action, with which an individual does not wish to be associated, is condemned by the international community as contrary to basic rules of human conduct, punishment for desertion or draft-evasion could, in the light of all other requirements of the definition, in itself be regarded as persecution" (Handbook, 1992: point 171). 


\section{Prohibition of apostasy}

In May 2014 the US Law Library of Congress, Global Legal Research Center published a study ${ }^{49}$ which identified rules that sanction the punishment of the abandonment of the Islamic faith in 23 African, Asian and MiddleEastern countries. In countries that closely obey Sharia the punishment is death. International press has reported on several cases in which the person to whom capital punishment had been meted out was in the end released due to international pressure. A recent example is that of Ms Mariam Ebrahim of Sudan, who married a Christian man. She was sentenced to 100 lashes for adultery and to death for apostasy in May 2014. (She has always considered herself a Christian, but according to Islamic rules she counted as Muslim, so having a relationship with a Christian was adultery.) Amnesty International collected more than a million signatures protesting the sentence and finally she was allowed to leave Sudan. ${ }^{50}$ The prohibition of apostasy sets apart the foreigner of whatever religion and the Muslim national, as punishment only threatens the latter (or, perhaps, all resident Muslims). ${ }^{51}$

\section{Ban on emigration}

Nowhere is the similarity between the faithful subject of the prince, king or emperor and the national of a sovereign state more pronounced than in the way the state binds a national to itself in her/his capacity as a labour force, potential soldier or financial resource (Torpey, 2000:18). Historically, the fight was not about the right to enter. It was about the right to leave! Feudalist and mercantilist approaches considered humans to be factors of production which would be lost in case of emigration, for which those societies (rulers, landlords) were not ready. One may recall rules that existed as late as the second half of the 19th century when European countries purported to control and manage emigration. The right to leave any country, including one's own,

49 Laws Criminalizing Apostasy in selected Jurisdictions The Law Library of Congress, Global Legal Research Center May, 2014

50 Sudanese woman spared death sentence for apostasy arrives in Italy http://www.theguardian.com/world/2014/jul/24/sudanese-woman-meriam-ibrahim-spareddeath-sentence-apostasy-italy (2014-07-26)

51 Space and time limitations prevent further scrutiny of the relevant penal codes with a view to establishing their personal scope. 
have become part of post-World War II human rights documents, ${ }^{52}$ but in practice many states have ignored them until today. Whoever lived in Central and Eastern Europe during Socialist times knows that hardly anything was more valuable than an exit visa and a passport allowing departure from the country. Leaving the country without a permit or denying return to it after a legal trip abroad was a crime and still is in the presently existing dictatorships.

It is a generally held view that control of the borders and of emigration and immigration is an indispensable part of sovereignty. However, as history before World War I and the present practice of the EU show, this is not the case (Nagy, 2012:35). Naturally, the control of border-crossings may have useful functions (apprehension of criminals, identifying children that are escaping their parents, preventing smuggling, or creating a barrier to epidemics) but none of these necessitate that the national be allowed to leave only in possession of an exit permit. Exit permits are only needed if the state wants to exercise decisive control over its nationals. Banning travel abroad under normal conditions - that is, when the state does not intend to hold the whole population as its hostage - is conceivable in strictly-determined cases, such as criminals fleeing procedure, in the case of persons with extremely large public debts, or when the person's identity is in doubt (until clarified).

\section{One-child policy}

The relationship between the state and the population living on its territory may become complicated. On the one hand, it may entail limitations on abortion for demographic or for religious-moral reasons. I will not address that problematique here, as - to the best of my knowledge - these rules apply to everyone on the territory, and their application is not limited to nationals. On the other hand, state interference with family planning may take the

52 The International Covenant on Civil and Political Rights states in its article 12 paragraph (2): "Everyone shall be free to leave any country, including his own". Paragraph (4) of the same Article assures the right to return. In the European Court of Justice case C-33/07 (Jipa) the court ruled that someone who had been removed from Belgium and therefore punished by a three year prohibition from leaving his home-country, Romania, must be allowed to leave, since a ban must be exceptional and rooted in the individual threat posed by the given person, which here was not the case. "The fact that a citizen of the Union has been subject to a measure repatriating him from the territory of another Member State, where he was residing illegally, may be taken into account by his Member State of origin for the purpose of restricting that citizen's right of free movement only to the extent that his personal conduct constitutes a genuine, present and sufficiently serious threat to one of the fundamental interests of society" - point 26. 
form of limiting the number of children a couple is supposed to have, as is the practice in China. This limitation is nationality-specific. ${ }^{53}$ The inhuman nature of the one-child policy is not in doubt as the violation of the rules may be sanctioned with a heavy fine, loss of public office, confiscation of personal assets and artificial sterilisation. ${ }^{54}$ States are divided about whether this generally-applied rule entitles those who flee China to refugee status ${ }^{55}$, but it is beyond doubt that the one child policy is a nationality specific burden.

\section{COMBINING THE THREADS - CONCLUSIONS AND SUGGESTIONS}

This study is not an assault on the institution of nationality. I take note of the fact that a great number of privileges (for example, in the EU: freedom of movement, the right to equal treatment, specific rights of EU citizens) derive from having a fortunate nationality. Neither am I forgetting that statelessness is even worse than having a less sought-after nationality

The study pursued several goals. First, it was written to show that the transformation of Hungarian public law, especially the rules related to nationality and national elections, has led to the construction of a contradictory system from the point of view of political philosophy. Second, it was designed to highlight the fact that certain nationalities place an unfair burden on those born into them.

I showed that the public discourse and the law irreconcilably contradict the unrevealed political intentions behind them. This contradiction leads to the impossibility of an orderly and seamless, harmonious use of the legal concepts that appear in the legal texts. The government has turned against its own rhetoric of a decade ago. Then the government of the same political colour and of the same prime minister denied the link between belonging

53 Order of the President of the People's Republic of China No. 63 The Population and Family Planning Law of the People's Republic of China, adopted at the 25th Meeting of the Standing Committee of the Ninth National People's Congress of the People's Republic of China on December 29, 2001, is hereby promulgated and shall go into effect as of September 1, 2002. Section 17. http://english.gov.cn/laws/2005-10/11/content_75954.htm (26.07.2014.)

54 See e.g. the decision of the Federal Magistrates Court of Australia: SZNCK v MINISTER FOR IMMIGRATION \& CITIZENSHIP, 28 May 2009 [2009] FMCA 399

http://www.refworld.org/cgi-bin/texis/vtx/rwmain?page $=$ search\&docid $=4 a 55$ c 4 c52\&skip $=0 \& q u e r y=S Z N C K \% 20 v \% 20 M I N I S T E R \% 20 F O R \% 20 I M M I G R A T I O N \% 20 \& \% 20$ CITIZENSHIP (2014-07-26)

55 Ibid., referring back to the Refugee Review Tribunal's position, refusing the application 
to the ethnic-cultural-historic nation and possessing Hungarian nationality. Now, at the level of rhetoric, the leading slogan is national reunification across borders with the help of the new public law regime: through preferential naturalisation and voting rights assigned to people who do not live in the country. But, in reality, this is not the real importance of the post 2010 setup. The new rules do not require any longer that the national declare herself to be Hungarian. Only descent from a former Hungarian national (of whatever ethnic-cultural background) and a minimal knowledge of the language are essential. This logic is imperial, it is clientele-building: descendants of the subjects of the Hungarian part of the Austro-Hungarian Monarchy may apply for preferential naturalisation and thereby become loyal voters of the power that acts to extend their opportunities.

In line with this, it has also become obvious that the idea of a self-governing political community is no longer applicable to Hungary. ${ }^{56}$ Power is not derived from the will of the Hungarian nationals, as 3-4 million of them are in effect "dumb", without practical access to a national's rights ${ }^{57}$. Nor can it be a product of the will of the population of Hungary as it includes hundreds of thousands of foreigners who have settled and are disenfranchised in national elections. "Popular will" is heavily influenced by more than a half million voters who have never lived in Hungary, but who as dual nationals have been preferentially naturalised and are entitled to vote on the national list of parties. The political community does not coincide with the Hungarian nation either, as several million people who identify themselves as Hungarian do not

56 The doctrine of the illiberal state was announced in a speech by the Prime Minister, $\mathrm{Mr}$ Orbán, symbolically not at home, but in Romania, Tusnádfürdő. "[T]he Hungarian nation is not simply a group of individuals but a community that must be organised, reinforced and in fact constructed. And so in this sense the new state that we are constructing in Hungary is an illiberal state, a non-liberal state. It does not reject the fundamental principles of liberalism such as freedom, and I could list a few more, but it does not make this ideology the central element of state organisation, but instead includes a different, special, national approach." He contrasted the illiberal state he plans to develop, with the liberal state of the years 1990 -2010. "The liberal democracy was incapable of openly stating and committing the prevailing government, including through the use of its constitutional powers, to serving the interests of the nation with their work. And it in fact challenged the very idea of the existence of national interests. It did not commit the prevailing government to accepting that Hungarians living throughout the world are part of the Hungarian nation and to try and reinforce this community through its work. The liberal democracy and liberal Hungarian state did not protect community assets." - Speech of Mr Viktor Orbán on 26 July 2014. http://www. miniszterelnok.hu/in_english_article/_prime_minister_viktor_orban_s_speech_at_the_25th_ balvanyos_summer_free_university_and_student_camp (2014-09-02)

57 Mere absence does not lead to loss of nationality, so the principle ius sanguinis is applicable without end. 
possess Hungarian nationality. So the population that expresses the popular vote as if it were a political community is in fact a set of people brought together by a capricious political will, primarily interested is perpetuating its power.

Moving beyond the misery of the conditions of Hungarian public law I argue that nationality in the $21^{\text {st }}$ century functions exactly as feudal privileges did once upon a time. In agreement with Joseph Carens and Ayelet Shachar ${ }^{58}$ I assert that the place of birth or the position of the parents determines the lifechances of the newly-born. If we regard it as unjust that someone born a serf should remain a serf all her life, and a born aristocrat remains one throughout theirs, or if we refuse the idea that the citizen of a town may live where a peasant is not allowed to settle, then we have to regard it unjust (morally untenable) that the "blood" of the parents (nationality in ius sanguinis systems) or the place of birth (in ius soli systems) determine the cluster of rights and duties of the individual (Shachar, 2009: 8-10, 24, 27).

What is the solution, then? A theory that prefers freedom and adheres to the inalienably equal dignity of every newly born must reduce the inequality of opportunities caused by the birthplace or by the nationality of the parents. ${ }^{59}$

Several options are available. It is common to them that they accept the existence of a surrounding community and the necessity of a society. Nevertheless, the suggested solutions share the conviction that birth into a community must not turn into an immutable fate. Locke was clear on that: "It is plain then, by the practice of governments themselves, as well as by the law of right reason, that a child is born a subject of no country or government. He is under his father's tuition and authority, till he comes to age of discretion; and then he is a freeman, at liberty what government he will put himself under, what body politic he will unite himself to..." (Locke, 1689/1764:§118)

My suggestion is that the bundle of rights enjoyed in the community/ society should correlate to the attachment to that community. Of course this should be understood as the bundle beyond basic human rights which

58 "Citizenship in Western liberal democracies is the modern equivalent of feudal privilege - an inherited status that greatly enhances one's life chances. Like feudal birthright privileges, restrictive citizenship is hard to justify when one thinks about it closely." (Carens 1987: 252); (Shachar, 2009:37-38).

59 For space reasons this study had to ignore the consequences of EU citizenship. This footnote nevertheless asserts that most of the benefits associated with nationality may be assured by entites smaller or larger than the state. See the consular protection offered by the EU, or the Common Foreign and Security Policy, which at the moment may still be in its infancy, but together with NATO may already be a firmer guarantor of security than the national defence apparatus. 
everyone everywhere should enjoy. Time and exposure to the decisions of the community together should determine the measure of influence and duty to contribute to the continuous existence of that community. "Stakeholder citizenship", says Rainer Bauböck, meaning that those persons should qualify as nationals (stakeholder citizens) whose lives are bound to the welfare of the given community. These are his words: "The notion of stakeholding expresses, first, the idea that citizens have not merely fundamental interests in the outcomes of the political process, but a claim to be represented as participants in that process. Second, stakeholding serves as a criterion for assessing claims to membership and voting rights. Individuals whose circumstances of life link their future well-being to the flourishing of a particular polity should be recognized as stakeholders in that polity with a claim to participate in collective decision-making processes that shape the shared future of this political community." (Bauböck, 2007:2422). "Ius nexi” suggests Ayelet Shachar, who argues that, "What is required here is not mere physical presence in the territory but also the passage of time and social connectedness, the latter referring to the requisite 'center of life' criteria, which itself can be interpreted in more generous or more stringent way" (Shachar, 2009:178). She proposes that mere presence alone should not lead to nationality. Actual manifestations of participation would be required, which in turn entails consequences for long-term absence. In fact, Sachar proposes that a second generation born abroad would no longer inherit nationality if there were no real connections to the polity (Shachar, 2009:180).

So, there are ways out from the jungle into which the Hungarian public laws adopted in the beginning of the 21st century have led. One only needs disciplined thinking and legislators who are receptive to the lessons of political-philosophy.

\section{REFERENCES}

Arendt, Hanna (1958), The Origins of Totalitarianism, Second ed, Cleveland, Meridian Books, The World Publishing Company

Bakk Miklós (2008): Politikai közösség és identitás. Kolozsvár, Komp-Press Kiadó Bar-Yaacov, Nissim(1961), Dual Nationality. London, Stevens and Sons

Bauböck, Rainer (2007), Stakeholder Citizenship and Transnational Political Participation: A Normative Evaluation of External Voting. Fordham Law Review. Vol. 75(5). pp. 2393-2447.

Carens, Joseph (1987): Aliens and citizens: the case for open borders. Review of Politics, Vol. 49. No. 2. pp. $251-273$. 
Csapody Tamás (2005), Utak és útvesztök - a sorkötelezettség története. Valóság, http://www.valosagonline.hu/index.php?oldal $=$ cikk\&cazon $=656 \& l a p=0$

Cserny Ákos (ed.) (2013), Alkotmányjog. Budapest, Nemzeti Köszszolgálati Egyetem

Frontex (2014), Annual Risk Analysis, Warsaw http://frontex.europa.eu/assets/ Publications/Risk_Analysis/Annual_Risk_Analysis_2014.pdf(02.09.2014)

Goffman, Erving (1986), Stigma: Notes on the Management of Spoiled Identity. New York, N.Y: Simon \& Schuster

Guild, Elspeth (2003), The border abroad - visas and border controls. In: Kees Groenendijk, Elspeth Guild és Paul Minderhoud (eds.): In search of Europe's Borders. The Hague, Kluwer, pp. 87-104.

Gyeney Laura (2013), Kettős állampolgárság az Európai Unió erőterében. Iustum Aequum Salutare Vol. IX., No. 2. pp.157-168.

Handbook on Procedures and Criteria for Determining Refugee Status under the 1951 Convention and the 1967 Protocol relating to the Status of Refugees HCR/IP/4/ Eng/REV.1 Geneva, UNHCR 1979 Reedited, January 1992

Howard, Marc Morjé (2005), Variation in Dual Citizenship Policies - in the Countries of the EU. International Migration Review Vol. 39(3) (Fall) pp. 697-720

Joppke, Christian (2010), The Inevitable Lightening of Citizenship. Archive of European Sociology (Archives européennes de sociologie), 2010, 51. 9 -32.

Kochenov, Dimitry (2010), Rounding up the Circle: The Mutation of Member States' Nationalities under the Pressure of EU Citizenship, EUI Working Papers RSCAS 2010/23

Locke, John (1689/1764), Second Treatise of Civil Government. https:/lebooks. adelaide.edu.au/l/locke/john/l81s/chapter8.html

Meloni, Annalisa (2006) Visa Policy within the European Union Structure. Berlin, Springer,

Molnár Tamás (2014), Remembering the forgotten: international legal regime protecting the stateless persons-stocktaking and new tendencies. US-China Law Review, Volume 11, Number 7, pp. 822-848.

Nagy Boldizsár (2012), A magyar menekültjog és menekültügy a rendszerváltozástól az Európai Unióba lépésig Erkölcsi, politikai-filozófiai és jogi vizsgálódások. Budapest, Gondolat, 2012.

Neumayer, Eric (2006), Unequal access to foreign spaces: how states use visa restrictions to regulate mobility in a globalized world. Transactions of the Institute of British Geographers, Vol. 31 No. 1.pp. 72-84.

Papp Imre (2003), A politikai részvételi jogok. In: Halmai Gábor és Tóth Gábor Attila (szerk.): Emberi jogok Budapest, Osiris, pp. 737 - 790.

Pogonyi, Szabolcs (2011), Dual citizenship and sovereignty. Nationalities Papers: The Journal of Nationalism and Ethnicity, Vol. 39, Issue 5, pp. 685-704.

Shachar, Ayelet (2009), The Birthright Lottery. Cambridge, Mass.Harvard University Press

Stibbe, Matthew (2006), The Internment of Civilians by Belligerent States during the First World War and the Response of the International Committee of the Red Cross. Journal of Contemporary History, Vol. 41, No. 1, pp. 5-19. 
Szarka László, Vizi Balázs, Majtényi Balázs és Kántor Zoltán (szerk.) (2007), Nemzetfogalmak és etnopolitikai modellek Kelet-Közép-Európában. Budapest, Gondolat, 2007.

Torpey, John (2000), The Invention of the Passport: Surveillance, Citizenship and the State. Cambridge, Cambridge University Press

Tóth, Judit (2013) Roma migration from a legal perspective. In: Vidra Zsuzsa (szerk.): Roma migration to and from Canada. The Czech, Hungarian and Slovak case. Budapest, CEU Press, pp. 23-52.

Tóth Judit (2004): Státusjogok. Budapest, Lucidus Kiadó, Kisebbségkutatás könyvek Tóth Pál Péter (1997), Haza csak egy van? Püski, 1997.

Walsh,Bernadette (1993), Detention and deportation of foreign nationals in the United Kingdom during the Gulf conflict. In: Rowe, Peter (ed.): The Gulf War 1990-91 in International and English Law, London Sweet \& Maxwell, pp. 268-293.

Waterbury, Myra A (2010), Between State and Nation. Diaspora Politics and KinState Nationalism in Hungary, New York, Palgrave Macmillan 